\title{
A survey on social networks to determine requirements for Learning Networks for professional development of university staff
}

Citation for published version (APA):

Brouns, F., Berlanga, A., Fetter, S., Van Bruggen, J., Sloep, P., \& Bitter, M. E. (2011). A survey on social networks to determine requirements for Learning Networks for professional development of university staff. International Journal of Web Based Communities, 7(3), 298-311. https://doi.org/10.1504/IJWBC.2011.041200

DOI:

10.1504/IJWBC.2011.041200

Document status and date:

Published: 01/01/2011

Document Version:

Peer reviewed version

\section{Document license:}

CC BY-NC-SA

Please check the document version of this publication:

- A submitted manuscript is the version of the article upon submission and before peer-review. There can be important differences between the submitted version and the official published version of record. People interested in the research are advised to contact the author for the final version of the publication, or visit the DOI to the publisher's website.

- The final author version and the galley proof are versions of the publication after peer review.

- The final published version features the final layout of the paper including the volume, issue and page numbers.

Link to publication

\section{General rights}

Copyright and moral rights for the publications made accessible in the public portal are retained by the authors and/or other copyright owners and it is a condition of accessing publications that users recognise and abide by the legal requirements associated with these rights.

- Users may download and print one copy of any publication from the public portal for the purpose of private study or research.

- You may not further distribute the material or use it for any profit-making activity or commercial gain

- You may freely distribute the URL identifying the publication in the public portal.

If the publication is distributed under the terms of Article $25 \mathrm{fa}$ of the Dutch Copyright Act, indicated by the "Taverne" license above, please follow below link for the End User Agreement:

https://www.ou.nl/taverne-agreement

Take down policy

If you believe that this document breaches copyright please contact us at:

pure-support@ou.nl

providing details and we will investigate your claim.

Downloaded from https://research.ou.nl/ on date: 26 Apr. 2023 


\title{
Learning Networks for professional development of university staff
}

\begin{abstract}
Learning Networks -online social networks where the learner is put central- are well suited for the non-formal professional development of academic staff. Our assumption is that Learning Networks can build on social network sites. Social network sites are becoming very popular and are very effective in connecting people, allowing exchange and sharing of all kinds of information and resources. Therefore we designed a survey to explore the use and perception of social network sites among academic staff and to relate this to the functionalities required for Learning Networks for professional development. The survey results indicate that a Learning Network should cater for the desired social aspects along with facilities to organise and maintain resources and contacts.
\end{abstract}

Keywords: Learning Network, social learning, professional development university staff, social network sites, continuous development, competence development, non-formal learning

\section{Introduction}

In several ways, improving the quality of the university is related to improving the competences of the staff -as teachers, researchers, management, and administration employees-. Staff requires, therefore, support to develop their competences in a way that they can improve their performance and have better chances to progress on their careers. From a lifelong learning perspective, such support is no longer restricted to formal education, informal and non-formal approaches have to be also taken into account (Sloep, 2008).

Learning Networks are particularly suitable to provide this kind of support. Learning Networks are online social networks that are designed to support non-formal learning in a particular domain in which the learner is placed centrally and takes on an important role (Sloep, 2008).

A Learning Network consists of a group of people who have to organise their own professional development, search for relevant resources, people and experts. Learners, at the same time, can take on any role and can participate -depending on the circumstancesas a learner, tutor or content provider. A Learning Network provides also learner support services that help learners in deciding which content and people are relevant to reach their learning goals (Koper, 2009).

Social learning refers to learning from others, with the use of technology and in particular Internet and Web2.0 applications. Most of the non-formal learning occurs in a social context: people learn from and by others. This happens in a social environment, e.g. work, or family. And it is becoming more common to look for others to ask for the 
relevant information instead of looking for content resources. People who grew up in the digital era are accustomed to using technology and the internet for their queries. Communities of practice, online communities and social network sites are examples in the Internet of social networks, based on social software. These sites are becoming very popular and are very effective in connecting people, allowing exchange and sharing of all kinds of information and resources. The features and functionalities of these kind of sites provide affordances for people that entice them to use the site and enhance the interaction between the members.

In earlier research we already indicated the importance of the characteristics of the participants and the community (Berlanga et al., 2008, Kester et al., 2007), along with design principles and guidelines to promote interaction and knowledge sharing (Kester and Sloep, 2009, Berlanga et al., 2009). Social space is one of the factors that facilitate knowledge transfer. Social space can be characterised as trust between participants, relies on affective relationships, sense of belonging and group cohesiveness (Berlanga et al., 2008, Kester et al., 2007). The social aspects of communities and interaction and exchange between participants are required to allow social space to emerge. Another condition that is required to initiate and maintain social interaction is the boundary condition. The boundary condition states that the goal and purpose of the community, or social network site has to be clear and known to the participants, and should be enforced by rules and policies (Kester et al., 2006, Sloep et al., 2007). In addition, successful communities provide functionalities to manage, organise, classify and regulate content and contact thereby promoting sustainability.

Our assumption is for Learning Networks to become effective learning environments, they should become and behave like a community (Kester et al., 2007). As social network sites are examples of successful online communities, we investigate what lesson we can learn from them and whether Learning Networks can build on social network sites. If arranged properly, they offer possibilities for social learning, where the learner decides what to study, where, when and with what facilities.

In this paper we explore whether Learning Networks can be build on the basis of social network sites. First we briefly describe social learning and the connection with Learning Networks. Next, we describe and present the results of a survey we conducted to investigate what features and functionalities university staff expect from a Learning Network for professional development as well as the role and function of social network sites in this. We discuss the results, also considering some interesting papers of the latest IADIS WBC and eLearning 2009 conference, and relate these to the design of a Learning Network for professional development.

\section{Social learning and Learning Networks}

Social learning refers to learning from other people, by other people, in a social setting and nowadays often with the application of social software. It no longer suffices to rely on traditional knowledge transfer. Society rapidly is transforming into a knowledge society and digital economy (European Commission, 2002). People need to develop existing and new competences; know how to apply skills and knowledge in different situations, but also how to use and apply the new technological innovations. Instead of relying on knowledge transfer, it has become more important to be able to find and locate relevant people and resources (Vassileva, 2008, Brown and Adler, 2008). The popularity 


\section{Learning networks for professional development of university staff}

of Web2.0 applications suggests that people now are more looking for access to other people instead of access to content as source for new information. Based on social constructivism and social learning theories (Vygotsky, 1978) people learn from other people and by interacting with others. In kind, members of communities of practice obtain new knowledge or learn through cooperation and collaboration (Wenger, 1999, Wenger et al., 2002). Also, learners who do not feel part of the community do not perform as well. In general, individual success or failure on a learning activity depends on the extent to which learners perceive themselves as participants of a community (Wegerif et al., 1998). And of course, the learner not only has to learn the required knowledge, but also has to practice and apply knowledge, skills and competences in practice.

Many companies already embrace social learning and apply social software for learning and knowledge exchange within their company. See for an example the group jazz (2006) for a case description. There also is a lot of literature on how to use and implement technology into education, including social software. King (2002) reported that teachers saw the benefits of incorporating technology into the curriculum, but also indicated the need to change the views on education when doing so. Moreover, there is quite some attention for the need to teach the teachers on this perspective, i.e. applying technology in traditional education (Hodgkinson-Williams and Siebörger, 2008, DuncanHowell, 2009). Although there are a number of initiatives for teacher training and communities of practice for educational professionals, there is much less so for university staff. In addition, these initiatives do not accommodate the increasing need for personalised, social learning, nor does it make use of paradigms of Web2.0 and in particular social network sites. Instead these are using new technology in a still top-down designed traditional educational setting. The new developments ask for a bottom-up organised setting, where the learner is put central, and a social approach where the learner learns in a social setting. Several aspects of this social setting can be found in numerous of the popular social network sites and are encouraged by Web2.0 applications. Social network sites allow people to share, interact, collaborate, and interact with other people with shared interests in an easy and innovative way. They provide features that allow people to easily find and locate people and content.

\section{Social software and social network sites}

While the World Wide Web started out mainly as one-way traffic, the onset of Web2.0 (O'Reilly, 2005) brought many new options for users. People not only can browse the web, but also can easily put content and information on the web using all kinds of applications, and share information with others. There is no longer a clear distinction between those that provide content and those that use the content. Instead, everybody can contribute and benefit from the information available in online communities, and use applications such as blogs, wikis, bookmarking applications, and online social network sites. Blogs and wikis allow people to write their own findings, reflections, reports, etcetera easily and make them available on the web for others to read. Wikis allow people to collaboratively write a contribution. Bookmarking applications allow people to keep track of their favourite pages, content, and websites and share them with others. Online communities or social network sites are Web2.0 applications that allow people to build their social network and/or exchange information and content. All these applications have 
found their way into traditional education (Bernsteiner et al., 2008, Alexander, 2006), as well as in the many informal and non-formal online communities of practice (like the many communities around open source software).

According to the European Commission (European Commission, n.d.) and a recent Nielsen report (2009) social network sites constitute the favourite online activity and the use of social network sites is growing constantly (cf. Comscore, (2009)). Examples of such social network sites are the sites that are intended to maintain personal networks by connecting to existing friends or meeting new people, like MySpace, Facebook, Hyves, or the popular file sharing sites where people upload content to share with others, like YouTube, Flickr, Picasa, etcetera. Everybody can create content, make it available to others as well as use it. People turn to these sites out of interest or to look for resources (both people and content) that could address their current need for information. These popular sites are effective due to the large amount of interaction between the participants. People decide what they are looking for and what information they exchange. The interaction and exchange is dedicated to their personal interests and needs. The popularity of these social network sites indicates that the sites apparently cover a need of the users and are effective in achieving this need. Although not particularly designed for learning, social network sites resemble Learning Networks in a sense, as social network sites also are created around a topic for which participants have a common interest, and allow people to exchange information. Similarly, Learning Networks evolve around people who are looking for certain information and resources (i.e. those that further their learning goals): they need to find relevant and suitable people, as well as find and contribute content. The design of the social network sites, functionalities and features used can inform the design of Learning Networks. When implementing Learning Networks, the design should encourage interaction and exchange mechanisms, either by providing the affordances, or by making use of existing social network sites and other Web2.0 applications.

\section{Important social network sites features for Learning Networks}

In this section we present a survey we conducted to investigate whether social network sites are a good starting point for the design of Learning Networks. In particular the survey should provide further insight into how familiar university staff is with existing social network sites, whether they actually use them and what for, what functionality they value, and what features and functions should be present in social networks sites designed for professional development.

For the survey we defined a social network site as a web-based service that allows people to (a) construct a profile within a system, (b) have a list of contacts, network or friends with whom they share a connection, and (c) view and navigate through their connections and those made by others within the system (boyd and Ellison, 2007).

The survey was provided online to 102 staff members -research, teaching, management, administration, ICT development- of an expertise centre for learning sciences and resulted in 42 valid responses. Respondents were asked to select as many of the social network sites listed in each of six categories or provide the name of another site when it was not listed. Next, we enquired into detail about reasons to join and to participate, role taken and valued characteristics for up to three social network sites to which the respondent had registered. We asked how respondents perceive social network 


\section{Learning networks for professional development of university staff}

sites, and what profiling affordances they expect. And finally, we asked what functionalities and features they would expect from a social network site for their personal professional development.

\section{Demographics}

Among the respondents, $56.4 \%$ was female, and $43.6 \%$ male. Average age was 42.3 years $(\mathrm{SD}=11.167, \min =25, \max =61)$, but with a mode at 27 and another one at 47 . Most were involved in research $(57 \%)$ or teaching $(21 \%)$, followed by management $(8 \%)$, administration/secretariat (8\%) and ICT development $(6 \%)$. Over half $(51.3 \%)$ held an MSc or comparable degree and $38.5 \%$ a $\mathrm{PhD}$, with backgrounds in psychology, education or educational technology.

The centre has two major research programmes and most respondents were active in these programmes: 29\% of respondents worked in the learning sciences research programme, and another $29 \%$ in a programme that is more oriented towards research and development of educational technology. However, in the learning sciences programme $82 \%$ was devoted to research and $12 \%$ to teaching, while in the R\&D programme, respondents mentioned a variety of activities: research still the main activity, followed by ICT development, teaching, administration, and management.

\section{Use of social network sites is still in exploratory phase}

The results indicated that staff are aware of social network sites, and know quite a lot of different social network sites, although most did not (yet) register.

Most respondents $(95 \%)$ provided the name of at least one social network site that they visited, with a range of 2 to 24 , and a total count of 311 representing some 60 different social network sites. In addition to the 30 different social network sites we listed for respondents to choose from, they added another 41 new names. However, only 20 social network sites were visited by more than 1 respondent. Moreover, the respondents visited mostly social network sites that can be classified as general, professional or special interest (Table 1). In particular the special interest sites were mentioned often with YouTube as favourite (Table 2).

Although respondents were familiar with quite some sites, actual participation as indicated by registration and usage time, was much lower. About $72 \%$ (29 out of 40 ) had registered to a social network site, although $12 \%$ never revisited the site. And some $28 \%$ indicated that they had not registered at all. Only 23 people indicated the social network site they used most frequently. Respondents mentioned 12 different social network sites they registered to, with a total count of 33. This is only a fraction of the count of 311 for visited sites. Surprisingly, people seemed to register to different sites than they visited. LinkedIn was mentioned 11 times, Hyves 5, Facebook and Plaxo 4, del.icio.us twice and the remaining 7 sites only once. Contrarily, YouTube -which is a popular visited site (32\% of special interest site visits (Table 2) and first position among all visited sites-, was mentioned only once as most used registered site. Therefore, the sites to which respondents registered, belonged more to the general and professional types of social network sites. Although some $44 \%$ had registered to the site for more than a year, only $13 \%$ visited the site on daily basis. 


\section{Author}

Table 1 Number of social network sites listed in each category, or mentioned by respondents in 'other'

\begin{tabular}{llllll}
\hline Category & $\begin{array}{l}\text { Number of } \\
\text { sites listed }\end{array}$ & $\begin{array}{l}\text { Number of other sites } \\
\text { mentioned by respondents }\end{array}$ & Number of cases & Count \\
\hline General & 8 & 8 & 33 & listed & other \\
Professional & 4 & 4 & 31 & 92 & 9 \\
Special interest & 5 & 10 & 40 & 48 & 5 \\
Hobby & 4 & 4 & 12 & 108 & 11 \\
Learning & 3 & 5 & 12 & 4 & 4 \\
Matching & 6 & 2 & 11 & 4 & 7 \\
Any other & $\mathrm{n} / \mathrm{a}$ & 11 & & $\mathrm{n} / \mathrm{a}$ & 11 \\
\hline Total & 30 & 44 & 263 & 48 \\
\hline
\end{tabular}

General: MySpace, Facebook, Hi5, Hyves, Schoolbank.nl, Ning, Tribe, Orkut;

Professional: LinkedIn, Ryze, Plaxo, Xing;

Special interest: Flickr, YouTube, LastFM, del.icio.us, Picasa;

Hobby: Catster, Dogster, Habbo Hotel, MyChurch;

Learning: Italki, Live Mocha, MyHappyPlanet;

Matching: Meetup, Match, Date, okCupid, Relatieplanet, Parship

Table 2 Top 5 of the visited social network sites (as count and \% of total count in each of the categories)

\begin{tabular}{lllll}
\hline Category & Name & Count & $\%$ & $\begin{array}{l}\text { total } \\
\text { count in } \\
\text { category }\end{array}$ \\
\hline General & Hyves & 25 & 24.75 & 101 \\
Professional & LinkedIn & 28 & 52.83 & 53 \\
Special interest & YouTube & 38 & 32.20 & 118 \\
Hobby & Habbo Hotel & 4 & 50 & 8 \\
Learning & Italki & 3 & 30 & 10 \\
Matching & Relatieplanet & 4 & 44.44 & 9 \\
Any other & 11 different & 1 & & 11 \\
\hline
\end{tabular}

\section{Social aspects attract}

The social dimensions of social networks sites seem to attract people to get started both with social network sites in general as for social network sites that are designed for professional development.

\section{2a. Social network sites in general}

The respondents valued in particular the social aspects of the social network sites, both for getting started with a social network site as during its use. Most respondents mentioned being invited by friends or others, keeping in touch, meeting new people, or 


\section{Learning networks for professional development of university staff}

communication as reasons to register and indicated that personal aspects are the most important purpose to participate (Table 3).

Table 3 Main purpose to participate in a social network site

\begin{tabular}{ll}
\hline & $\%$ \\
\hline Personal networking & 23.5 \\
Keeping in touch with people I know (family/friends) & 17.6 \\
Socializing & 13.2 \\
Leisure/fun/hobby & 11.8 \\
Meet new people & 8.8 \\
Expertise sharing & 8.8 \\
Acquiring new knowledge & 7.4 \\
Business & 7.4 \\
Develop new competences & 1.5 \\
\hline
\end{tabular}

When asked which characteristics of the social network site people appreciate the most, 13 out of 17 respondents indicated again the social aspects, like keeping in touch, networking, meeting new people to be most important, while only three mentioned functions like navigation, usability and recommendations and a single respondent indicated sharing of knowledge. These aspects were also mentioned as the benefits of social network sites or the reason why they would encourage others to join the site. Functionalities to add contacts, browse other people's contacts and create a personal profile were ranked most often in first and second place.

This is also reflected in the roles people take on in the social network site. Although people took on multiple roles and equally classified themselves as being a listener and somebody who contributed content, as additional roles they mentioned some form of communication: to make little comments, chat; communicate with my friends; I maintain contact with people; keep my profile updated; invite/accept others; check out people's CVs; sometimes look for job opportunities; react on messages of others.

\section{2b. Social network sites designed for professional development}

When we enquired about characteristics and functionalities that respondents expect in a social network site for professional development, again social aspects were among the main reasons to join, or seen as conducive towards professional development. Respondents indicated that they look for:

- types of people, experts;

- $\quad$ both synchronous and asynchronous communication facilities;

- indication of trustworthiness and quality of participants: experts who can teach me something; people I know; people I trust, information about expertise and interest;

- learning support: recommendation on people and resources; access to people and expert for support;

- how do I compare to others, list of people who reached competence. 
As reasons for helping others, altruistic reasons were mentioned quite often, as well as expecting help in return, or helping because they know the person, or it is something you do among colleagues. Several would help only when they already have the expertise and knowledge, while some will do so to increase their own knowledge or skills.

\section{Boundary, sustainability, usability and privacy affect participation}

While the social aspects seem to entice people to join and participate in social network sites, factors like the boundary condition, functionalities that enable participants to manage, organise and classify, determine whether participants keep using the site. Respondents indicated this for social network sites in general as well as for social network sites designed for professional development.

\section{3a. Social network sites in general}

Respondents mentioned access to and sharing of resources only after social aspects as main reason to join and participate in a social network site. A clear purpose (boundary) seems important as respondents stopped using social network sites because they got disappointed and the sites did not meet their expectations.

Additionally, the preference for information about occupation, interest and expertise, followed by real name and school/university in the user profile indicates that the purpose of the site and possibilities to classify and categorise people is relevant for participation and contribution.

The majority of the respondents mentioned as drawbacks that participation was very time consuming. As reasons to stop using the social network sites were mentioned: too time consuming, low usability, no added value, better alternatives available, and privacy. Quite a few respondents were concerned about privacy (having to register, having to register at multiple sites, not being able to fully control what is shown and shared). Several indicated that there are too many comparable sites to choose from.

\section{3b. Social network sites designed for professional development}

In a social network site that is designed for professional development, respondents looked more towards boundary and sustainability functionalities. Reasons to join and desired affordances for professional development focus around being able to classify and categorise people and resources and the purpose of the site. Such as:

- $\quad$ assist in determining the learning goal; description of competences; list of goals to choose from; clear goal; structure; access to learning materials relevant to goal;

- $\quad$ proven quality of resources and learning material: learning resources and activities; worked out examples by experts; interesting course material; experts; people I can trust; people I know;

- $\quad$ ability to bring in own content; usability; overview of people's networks; mash-up of existing services.

Respondents indicated above all functionalities and features that relate to boundary (expectations, functionality, goal) and usability (ease of use, reliability, user-friendly, 


\section{Learning networks for professional development of university staff}

appealing interface) as desired features in the social network site that would motivate them to learn. Indicators of effectiveness and usability, as well as of a dynamic community were mentioned too.

\section{Context is relevant}

Respondents participated in social network sites mostly for personal reasons. The context in which the staff operates and their main interest has some influence on whether they use social network sites and which type they are interested in.

At first instance it seemed that research staff visit and use social network sites much more than teaching staff. When we correct this for the number of respondents in each of the areas (56\% in research, against $20 \%$ in teaching), this distinction no longer can be made. Both teaching and research staff seem to favour general social network sites (Table 4).

Table 4 Average number of visited sites by teaching and research staff

\begin{tabular}{lll}
\hline & Teaching & Research \\
\hline General & $4.3(1.9)$ & $3.2(1.6)$ \\
Professional & $1.7(0.7)$ & $1.8(0.8)$ \\
Special interest & $3.8(1.2)$ & $2.9(1.6)$ \\
\hline Total count & 91 & 228 \\
Number of cases & 35 & 107 \\
\hline
\end{tabular}

The same number of people from the instructional design research programme as from the technology development research programme indicated which social network sites they visited. The technology oriented staff seemed to favour the special interest sites, as compared to the staff from the educational research programme, who visited on average more general social network sites (Table 5).

Table 5 Number of visited sites in the traditional instructional design research programme and the technology development oriented research programme

\begin{tabular}{|c|c|c|c|c|c|c|c|c|c|c|}
\hline & \multicolumn{5}{|c|}{ Instructional design research } & \multicolumn{5}{|c|}{ Technology development } \\
\hline & $\mathrm{N}$ & Sum & $\begin{array}{l}\text { Mean } \\
\text { (SD) }\end{array}$ & Min & Max & $\mathrm{N}$ & Sum & $\begin{array}{l}\text { Mean } \\
\text { (SD) }\end{array}$ & Min & $\operatorname{Max}$ \\
\hline General & 9 & 24 & $\begin{array}{l}2.67 \\
(0.86)\end{array}$ & 2 & 4 & 9 & 33 & $\begin{array}{l}3.67 \\
(1.87)\end{array}$ & 1 & 7 \\
\hline Professional & 8 & 12 & $\begin{array}{l}1.5 \\
(0.76)\end{array}$ & 1 & 3 & 10 & 18 & $\begin{array}{l}1.8 \\
(0.79)\end{array}$ & 1 & 3 \\
\hline Special interest & 11 & 21 & $\begin{array}{l}1.9 \\
(1.22)\end{array}$ & 1 & 4 & 11 & 41 & $\begin{array}{l}3.72 \\
(1.56)\end{array}$ & 1 & 6 \\
\hline Hobby & 5 & 5 & $1.0(0)$ & 1 & 1 & 2 & 2 & $1.0(0)$ & 1 & 1 \\
\hline Learning & 5 & 5 & $1.0(0)$ & 1 & 1 & 4 & 4 & $1.0(0)$ & 1 & 1 \\
\hline Matching & 4 & 4 & $1.0(0)$ & 1 & 1 & 4 & 9 & $\begin{array}{l}2.25 \\
(0.96)\end{array}$ & 1 & 3 \\
\hline Any other & 3 & 3 & $1.0(0)$ & 1 & 1 & 4 & 4 & $1.0(0)$ & 1 & 1 \\
\hline
\end{tabular}


Respondents indicated that they used social network sites equally in personal and work context, but registered to 17 sites in personal context and 10 sites in work context. Moreover, in work context, staff used more the professional and special interest sites (LinkedIn 7, Plaxo 3 and del.icio.us 1), while in personal context people used the general sites more (Hyves 5, Facebook 3, LinkedIn 2). Respondents were rather neutral about the importance of the sites for their professional activities or personal life, but considered the site to be more important for personal life than for professional activities. The sites mentioned in the work context are, just like the sites used in personal context, networking sites. And in that sense are probably more used towards finding people for collaboration or maybe job offerings, instead of professional development, or incorporated into their daily activities, such as teaching.

\section{Learner support and material expectations}

Respondents turn to other participants for answers to content related questions, feedback, collaboration and advice on how to proceed. By far most respondents preferred a combination of being able to select potential people from a list and a service that suggests relevant people when they require support from another person.

Self-study material was ranked highest, followed by following courses and being able to contact experts, while being able to contact experts, being able to find participants that can help you, getting a recommendation from the system who can help you or getting a recommendation from other participants about who can help you were ranked lower

Respondents were not very explicit on the kind of type of learning material they looked for. They mostly used general terms such as courses, learning resources, learning materials, workshops, or even only interesting and useful information. Occasionally they qualified it by specifying good learning resources, good courses, courses of high quality, effective learning opportunities. Some were more specific: music, fun, multimedia, great examples by experts, documented experiences by others.

\section{Discussion}

The survey offers some good indications on what people expect from social network sites in general and in particular those intended for professional development.

This relatively small group of professionals was familiar with an extensive list of 60 social network sites. Although there was a lot of interest in all kinds of file sharing sites, the respondents did not actively contribute to these sites. They seem to participate in social network sites mainly for the personal aspects. Apparently they are looking for ways to maintain and elaborate their network, and contact people. This is supported by findings in literature, where students indicated the lack of face-to-face communication to be the largest problem in online education and that social presence is required (Stodel et al., 2006). There is some influence from the professional context and type of work-related activities the staff is involved in. The more technology oriented staff is more explorative and active in more varied sites, due to the nature of their activities. 


\section{Learning networks for professional development of university staff}

The results suggest that Learning Networks should encompass at least those functionalities of social network sites that make those thrive. In general, the picture arises that respondents are looking in particular for functionalities that allow them to categorise and classify people in order to facilitate the social aspects of interaction and collaboration, next to features that allow them to manage content and people to allow exchange of information. It was clear from the reactions that many social network sites do not meet the expectations of the users. This could be because people have incorrect expectations about the purpose of the social network site, because the purpose and boundary were not clearly defined, the usability was poor, or quality of content and resources was poor. Other concerns mentioned were the many alternative sites with approximately the same function, the demand on time, having to register for every single social network site, not sufficient control over public and private information.

For social network sites for professional learning, categorisation features to be able to judge quality of resources and network members become more important. It was striking that, next to suitable materials, respondents expected known experts to be available. Although some mentioned that they expect peers and other people to be present, apparently they need a clear indication of quality before approaching them for a learning purpose. Others already pointed out that contribution and participation to online communities can be improved by visualising the members and the actions they take (Millen and Patterson, 2002, Erickson and Kellogg, 2000). This again points to the social dimension of the social network site, but with a dimension of quality control of the resources, both in material as human resources. In contrast, respondents were more than willing to help out peers who have a question, provided it would be cost-effective (in time spent and expected support in return). This is supported by findings in literature, e.g. (Plickert et al., 2007, Cheng and Vassileva, 2005, van Rosmalen et al., 2008).

People expect high quality learning material in Learning Networks, but more so features that allow participants to categorise, rate and judge quality of contributions, members and learning resources, next to a suitable and relevant learning support structure consisting of relevant experts and peers. Care should be taken to present clearly the purpose and boundary of the Learning Network, showing benefits over other sites. This has to be facilitated with a clear navigation and user interface, and high usability of the site. A Learning Network should allow participants to combine their profiles from existing sites and determine what information is publicly shared.

Several papers at the recent IADIS MCCSIS 2009 conference also pointed out the need for a more non-formal approach towards professional development, one that takes into account individuals' needs and incorporates opportunities social software and social network sites offer (Mansvelt et al., 2009, Bunt-Kokhuis, 2009, Jump et al., 2009, Bortoli et al., 2009).

The findings of our survey support our assumption that Learning Networks should contain characteristics of popular social network sites. A strong focus should lie on encouraging social interaction, sharing of information and incentives that motivate to exchange and learn. This is supported by several papers presented Currently we are preparing a prototype to investigate how a Learning Network can be designed using existing social network sites based on Web2.0 technologies (OpenSocial and mash-ups). 


\section{References}

Alexander, B. (2006) Web 2.0 A New Wave of Innovation For Teaching And Learning? Educause Review, 33-44.

Berlanga, A., Rusman, E., Bitter-Rijpkema, M. \& Sloep, P. (2009) Guidelines To Foster Interaction In Online Communities. In Koper, R. (Ed.) Learning Network Services For Professional Development. Springer Verlag.

Berlanga, A., Sloep, P. B., Kester, L., Brouns, F., Van Rosmalen, P. \& Koper, R. (2008) Ad Hoc Transient Communities: Towards Fostering Knowledge Sharing In Learning Networks. International Journal of Learning Technology, 3, 443-458.

Bernsteiner, R., Ostermann, H. \& Staudinger, R. (2008) Facilitating E-Learning With Social Software: Attitudes And Usage From The Student's Point Of View. International Journal of Web-Based Learning And Teaching Technologies, 3, 16-33.

Bortoli, S., Palpanas, T. \& Bouquet, P. (2009) Pulling Down The Walled Garden: Towards A Paradigm For Decentralized Social Network Management. In Bradley, G. \& Kommers, P. (Eds.) Iadis Multi Conference On Computer Science And Information Systems. Web Based Communities 2009. Algarve, Portugal, Iadis.

Boyd, D. M. \& Ellison, N. B., 13(1),

Http://Jcmc.Indiana.Edu/Vol13/Issue1/Boyd.Ellison.Html (2007) Social Network Sites: Definition, History, And Scholarship. Journal Of Computer-Mediated Communication, 13.

Brown, J. S. \& Adler, R. P. (2008) Minds On Fire: Open Education, The Long Tail, And Learning 2.0. Educause Review, 43, 16-32.

Bunt-Kokhuis, S. V. D. (2009) Talent Keys For Lifelong E-Learners. In Nunes, M. B. \& Mcpherson, M. (Eds.) IADIS Multi Conference On Computer Science And Information Systems. E-Learning 2009. Algarve, Portugal, Iadis.

Cheng, R. \& Vassileva, J. (Eds.) (2005) User Motivation And Persuasion Strategy For Peer-To-Peer Communities.

Comscore (2009) Social Networking Has Banner Year In France, Growing 45 Percent.

Duncan-Howell, J. (2009) Teachers Making Connections: Online Communities As A Source Of Professional Learning. British Journal of Educational Technology, 9999.

Erickson, T. \& Kellogg, W. A. (2000) Social Translucence: An Approach To Designing Systems That Support Social Processes. ACM Transactions On Computer-Human Interaction (Tochi). Special Issue On Human-Computer Interaction In The New Millennium. Part 1, 7, 59-83.

European Commission (2002) Towards A Knowledge-Based Europe. The European Union And The Information Society.

European Commission (N.D.) Making The Most Of Social Networking.

Group Jazz (2006) Building A Transformative Network: Ibm Virtual Learning Community Case Study.

Hodgkinson-Williams, C. \& Siebörger, H. S. I. (2008) Developing Communities Of Practice Within And Outside Higher Education Institutions. British Journal of Educational Technology, 39, 433-442.

Jump, L., Jump, R. \& Gill, A. (2009) Learning In Context: Using The Concept Of 'Community Of Practice' As A Framework To Evaluate An Online Masters Programme. 
In Nunes, M. B. \& Mcpherson, M. (Eds.) IADIS Multi Conference On Computer Science And Information Systems. E-Learning 2009. Algarve, Portugal, Iadis.

Kester, L. \& Sloep, P. (2009) Knowledge Dating And Knowledge Sharing In Ad-Hoc Transient Communities. In Koper, R. (Ed.) Learning Network Services For Professional Development. Springer Verlag.

Kester, L., Sloep, P. B., Van Rosmalen, P., Brouns, F., Koné, M. \& Koper, R. (2007) Facilitating Community Building In Learning Networks Through Peer-Tutoring In Ad Hoc Transient Communities. International Journal of Web Based Communities, 3, 198205.

Kester, L., Van Rosmalen, P., Sloep, P., Brouns, F., Brouwers, M. \& Koper, R. (2006) Matchmaking In Learning Networks: A System To Support Knowledge Sharing. International Workshop In Learning Networks For Lifelong Competence Development, Tencompetence Conference. Sofia, Bulgaria, Tencompetence.

King, K. P. (2002) Educational Technology Professional Development As Transformative Learning Opportunities. Computers \& Education, 39, 283-297.

Koper, R. (Ed.) (2009) Learning Network Services For Professional Development, Springer.

Mansvelt, J., Suddaby, G. \& O'hara, D. (2009) Professional Development In Elearning: Reflections And Implications From A National Research Project. In Nunes, M. B. \& Mcpherson, M. (Eds.) IADIS Multi Conference On Computer Science And Information Systems. E-Learning 2009. Algarve, Portugal, Iadis.

Millen, D. R. \& Patterson, J. F. (2002) Stimulating Social Engagement In A Community Network. Cscw '02. New Orleans, Louisiana, Usa, Acm Press, New York, Ny.

Nielsen (2009) Social Networks \& Blogs Now 4th Most Popular Online Activity, Ahead Of Personal Email, Nielsen Reports.

O'Reilly, T. (2005) What Is Web 2.0 Design Patterns And Business Models For The Next Generation Of Software.

Plickert, G., Côté, R. R. \& Wellman, B. (2007) It's Not Who You Know, It's How You Know Them: Who Exchanges What With Whom? Social Networks, 29, 405-429.

Sloep, P. B. (2008) Fostering Sociability In Learning Networks Through Ad-Hoc Transient Communities. In Purvis, M. \& Savarimuthu, B. T. R. (Eds.) ComputerMediated Social Networking. First International Conference On Computer Mediated Social Networking, Iccmsn 2008. Dunedin, New Zealand, Springer, Heidelberg, Germany.

Sloep, P. B., Kester, L., Brouns, F., Van Rosmalen, P., De Vries, F., De Croock, M. \& Koper, R. (2007) Ad Hoc Transient Communities To Enhance Social Interaction And Spread Tutor Responsibilities. In Uskov, V. (Ed.) Sixth International Conference On Web-Based Education WBE 2007. Chamonix, France, Acta Press.

Stodel, E., J., Thompson, T. L. \& Macdonald, C., J. (2006) Learners' Perspectives On What Is Missing From Online Learning: Interpretations Through The Community of Inquiry Framework.

Van Rosmalen, P., Sloep, P. B., Brouns, F., Kester, L., Berlanga, A., Bitter, M. \& Koper, R. (2008) A Model For Online Learner Support Based On Selecting Appropriate Peer Tutors Journal Of Computer Assisted Learning, 24, 483-493.

Vassileva, J. (2008) Toward Social Learning Environments. IEEE Transactions On Learning Technologies, 1, 199-214.

Vygotsky, L. S. (1978) Mind In Society, Cambridge, Ma, Harvard University Press. 


\section{Author}

Wegerif, R., Mercer, N. \& Dawes, L. (1998) Software Design To Support Discussion In The Primary Curriculum. Journal of Computer Assisted Learning, 14, 199-211.

Wenger, E. (1999) Communities of Practice: Learning, Meaning, And Identity, Cambridge, Cambridge.

Wenger, E., Mcdermott, R. \& Snyder, W. (2002) Cultivating Communities of Practice: A Guide To Managing Knowledge, Cambridge, Ma., Harvard Business School Press. 